\title{
Two Cases of Seronegative Paraneoplastic Neurologic Syndrome with Opsoclonus Nystagmus
}

\author{
Seong Hoon Bae ${ }^{\mathbb{D}}$, Jeon Mi Lee, and Sung Huhn Kim ${ }^{\mathbb{D}}$ \\ Department of Otorhinolaryngology, Yonsei University College of Medicine, Seoul, Korea \\ 안진검사에서 안구간대경련을 보인 혈청 음성 신생물딸림신경증후군 2예 \\ 배성훈 · 이전미 · 김성헌 \\ 연세대학교 의과대학 이비인후과학교실
}

\author{
Received May 19, 2018 \\ Revised July 26, 2018 \\ Accepted July 27, 2018 \\ Address for correspondence \\ Sung Huhn Kim, MD, PhD \\ Department of Otorhinolaryngology, \\ Yonsei University \\ College of Medicine, \\ 50 Yonsei-ro, Seodaemun-gu, \\ Seoul 03722 , Korea \\ Tel $+82-2-2228-3624$ \\ Fax $+82-2-393-0580$ \\ E-mail fledermaus@yuhs.ac
}

The dizziness associated with paraneoplastic neurologic syndrome is hard to diagnose clinically because the prevalence of disease is rare, and radiologic and serologic examination result may come out normal. Opsoclonus-myoclonus symdrome is a representative of classical paraneoplastic neurologic syndromes. In this paper, we report 2 cases of paraneoplastic neurologic syndromes with negative serologic auto-antibody test and no brain lesion on MRI. Both cases were eventually diagnosed through PET. Patients with opsoclonus-myoclonus type nystagmus should be evaluated for paraneoplastic neurologic syndrome even if their radiologic and serologic findings are normal. Korean J Otorhinolaryngol-Head Neck Surg 2019;62(6):355-60

Key Words Myoclonus · Nystagmus · Opsoclonus-myoclonus syndrome · Paraneoplastic syndrome, neurologic.

\section{서 론}

이비인후과에 어지럼증을 주소로 내원하는 환자들을 진 료할 때 가장 중요한 것은, 그 원인이 중추성인지 말초성인지 여부를 감별하는 것이다. 두 어지럼증의 감별은 대부분 세밀 한 병력청취와 신경학적 진찰에 의해 가능하지만, 일반적으 로 자기공명영상(MRI)을 통해 중추전정계 즉 전정피질, 시상, 뇌간 및 소뇌 등에서 병변을 확인함으로써 확진할 수 있다. 그러나 드물지만 영상의학적 검사로 발견되지 않는 중추성 어지럼증도 존재한다. 그 대표적인 경우가 신생물딸림증후군 (paraneoplastic syndrome)에 의한 어지럼증이다.

신생물딸림증후군(paraneoplastic syndrome)이란 악성 종 양을 갖고 있는 환자에서 종양 자체의 침윤이나 전이, 영양실 조, 감염, 항암치료의 부작용 등과는 관계없이 나타나는 여

This is an Open Access article distributed under the terms of the Creative Commons Attribution Non-Commercial License (https://creativecommons.org/licenses/by-nc/4.0) which permits unrestricted non-commercial use, distribution, and reproduction in any medium, provided the original work is properly cited.
러 증상들을 통칭한다. ${ }^{1)}$ 신생물딸림증후군의 하나인 신생물 딸림신경증후군(paraneoplastic neurologic syndrome)은 주 요 증상으로 어지럼증과 함께 중추성 안진을 유발하는 대표 적인 질병으로 알려져 있으며, 특히 소세포폐암, 부인과 종양, 유방암 및 호지킨임파선암에서 많이 발생한다. ${ }^{2)}$ 그 기전은 신생물과 관련된 자가항체가 소뇌의 특정 부위에 면역반응 을 일으키며 조직을 손상시켜 증상을 유발하는 것으로 알려 져 있다. ${ }^{3)}$ 때문에 이는 일반적인 영상의학적 검사에서 잘 발견 되지 않아 양전자방출단층촬영(PET)이나 자가항체검사 등 전신적인 검사를 필요로 하기도 한다.

안구간대경련-근간대경련증후군(opsocolus-myoclonus syndrome)은 신생물딸림신경증후군의 전형적 증후군(classical syndrome)으로 분류되며, 눈의 불수의적이고 불규칙적 인 발작적 움직임과 사지 근육의 갑작스럽고 빠른 불수의적 수축이 함께 나타나는 상태를 뜻한다. 비록 이 증상은 여러 가지 원인에 의해 유발될 수 있지만 많은 경우에서 신생물딸 림신경증후군에 의해 발생한다고 보고되었다. ${ }^{4)}$ 따라서 환자 
가 신체검사에서 안구간대경련과 근간대경련을 보일 때에는 중추성 어지럼증을 꼭 감별해야 하는 것으로 알려져 있다. ${ }^{5}$

국내에는 $\mathrm{Kim}$ 등 ${ }^{6}$ 이 신경계자가항체(anti-Ri antibody)가 검출된 신생물딸림신경증후군에 의한 안구간대경련-근간대 경련증후군 환자 1 명의 증례를 보고하였다. 또한 Lee 등ㄱ은 신생물딸림증후군으로 발생한 뇌신경마비 1예를 보고하였으 며, 이 증례의 경우 신경계자가항체는 발견되지 않았다. 이에, 본 저자들은 신경계자가항체가 발견되지 않은 신생물딸림신 경증후군에 의한 안구간대경련-근간대경련증후군 2 예를 문 헌 고찰과 함께 국내에서 최초로 보고하고자 한다.

\section{증 겨}

\section{증 례 1}

74세 남자 환자가 20일 전부터 발생한 어지럼증과 근육이 튀는 증상을 주소로 응급실로 내원하여 이비인후과로 협진 의뢰되었다. 고혈압, 통풍 외에 다른 과거력은 없었던 환자로 정신을 잃을 것 같은 느낌의 비회전성 어지럼증 양상이었고, 오심과 구토를 동반하고 있었다.

이학적 검사상 안진의 양상은 불수의적이고 불규칙하여 안 구간대경련으로 보였고 환자가 호소하는 근육이 튀는 현상은 근간대경련의 양상이었다. 또한 앉은 상태에서 몸의 중심을 잡 지 못하여 쓰러지는 체간성실조(truncal ataxia)가 관찰되었다.

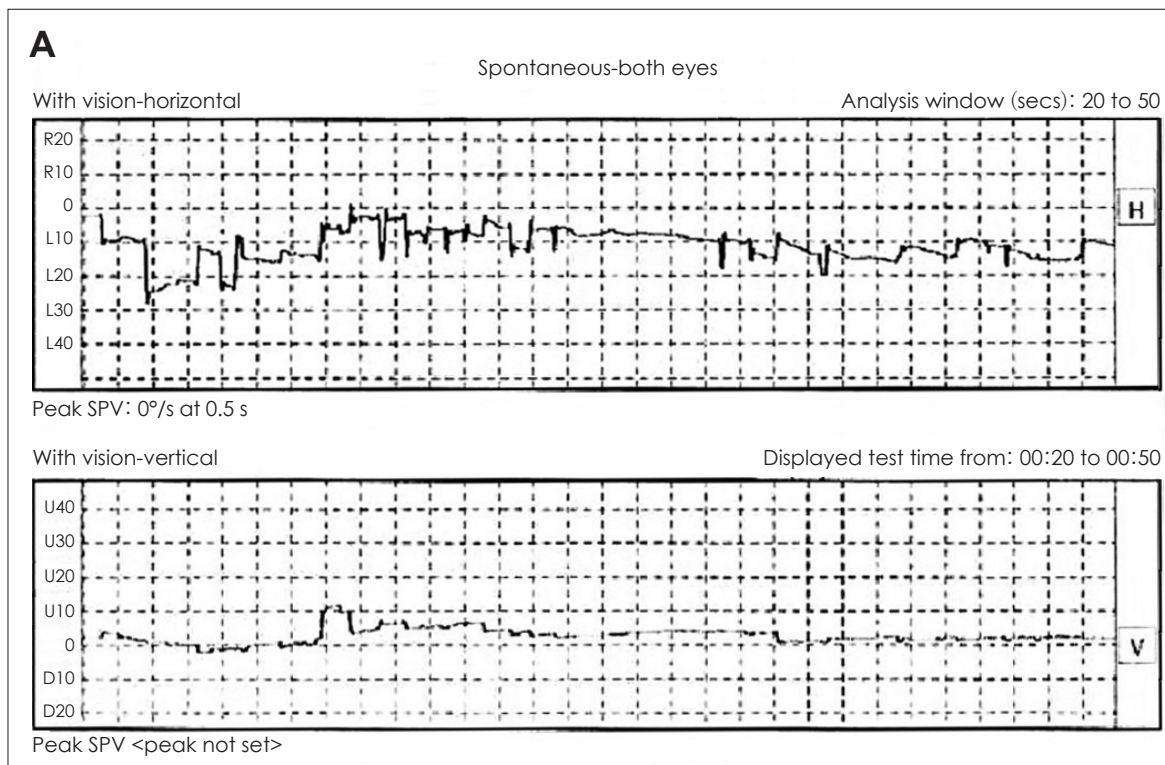

\section{B}

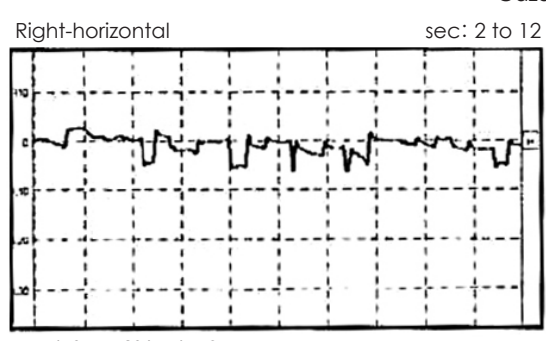

Peak SPV: $2 \%$ s at $7.0 \mathrm{~s}$

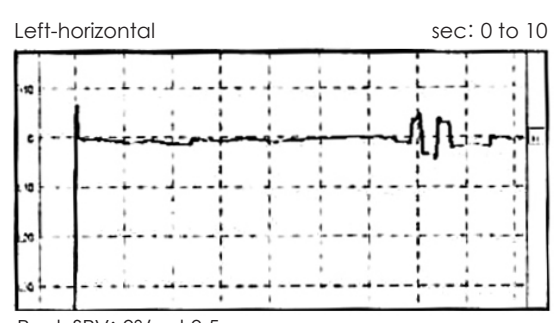

Peak SPV: $0 \% \mathrm{~s}$ at $0.5 \mathrm{~s}$
Gaze-both eyes

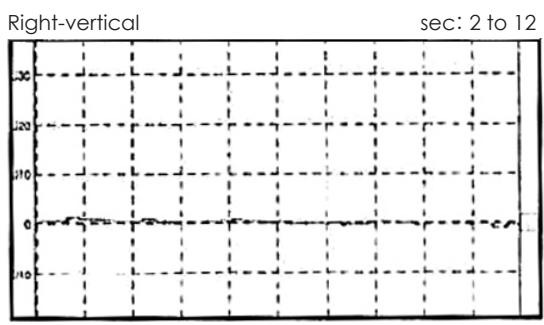

Peak SPV <peak not set>

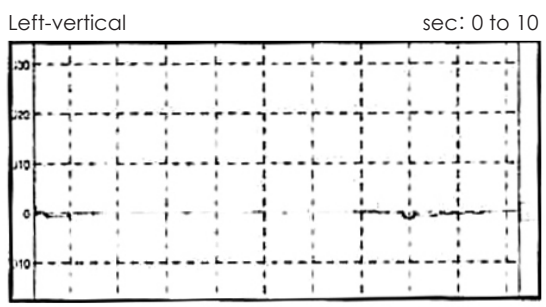

Peak SPV <peak not set>
Fig. 1. Videonystagmography of the patient. Spontaneous; irregular, arrhythmic spontaneous eye movement (A) and Gaze; same as above (B). SPV: slow phase peak velocity. 
외부에서 시행한 전정기능검사에서 불규칙하고 방향성이 없는 안구간대경련 양상의 안진이 확인되었다(Fig. 1). 자발 안진검사 및 주시안진검사에서는 속도와 방향이 불규칙한 안진이 보였고 단일온도안진검사(ice caloric test)에서는 양측 에서 정상소견을 보였다(Fig. 2). 체위기록법(posturography) 은 시행하지 않았다.

안진과 어지럼증의 양상으로 중추성 어지럼증이 의심되어 뇌 자기공명영상을 시행하였으나 특이 소견은 보이지 않았다. 자가항체검사(ANA, anti-dsDNA, P-ANCA, C-ANCA)에 서 항체는 모두 검출되지 않았고 신경계자가항체검사(anti-Hu, anti-Ri, anti-Yo, anti-NMO) 역시 어떤 항체도 검출되지 않 았다. 상기 자가항체검사는 서울아산병원 진단검사의학과에 위탁하여 시행하였으며 쥐의 위, 소뇌, 신장 조직과 환자의 혈 청을 간접면역형광염색을 시행하여 항원-항체반응이 있는지 조사하는 방법을 사용하였고 세 종류의 조직 모두에서 면역 반응은 나타나지 않았다. 하지만 종양표지자 검사에서 폐암 의 표지자인 CYFRA21-1과 NMP22가 참고치보다 높게 측 정되었고, 양전자방출단층촬영(PET-CT)에서 폐의 좌하엽 과 종격동림프절에서 조영증강 소견을 보여, 흥부 컴퓨터단층 촬영(Chest CT)과 경기관지폐생검(transbronchial lung biopsy) 을 통하여 소세포폐암(small cell lung cancer)을 진단하였 다(Fig. 3).

폐암의 확진 이후 환자는 종양내과로 전과 되어 Etoposide/ Carboplatin 항암치료 1차 시행 후 퇴원하였고 현재는 추적 관 찰이 되지 않는 상태이다.

\section{증 례 2}

36세 여자 환자가 일주일 전부터 발생한 회전성 어지럼증을
주소로 내원하였다. 환자는 한달 전 동일 증상으로 급성전정 신경염으로 진단받고 스테로이드 약물치료 후 증상이 호전된 과거력이 있으며 다른 내과적, 이비인후과적 과거력은 없었다.

환자는 일주일 전부터 발생한 오심과 구토를 동반한 회전 성 어지럼증 및 보행장애를 호소하였으며 청력저하, 이통, 이 루, 이충만감 등은 보이지 않았다. 어지럼증은 지속적이었으 며 자세 변화에 따라 악화 혹은 완화되지 않았다. 당시 신체 검사에서 자발 안진이 관찰되었으며 그 양상은 발작적이고 불규칙적이며, 안진의 빠른 성분과 느린 성분이 잘 구분되지 않는 안구간대경련(opsoclonus)을 보이고 있었다. 지속적인 자발안진과 현훈 증상으로 두부충동검사와 두위변환안진검 사는 시행하지 못했고, 주시안진검사에서 안진 방향의 변화 는 없었다. 환자는 구음, 연하 및 사지의 운동신경과 감각신 경의 장애는 없었으나, 일자보행(tandem gait) 중 양측으로 몸 통의 흔들림이 심하게 나타나 보행이 불가능했으며, 롬버그 검사(Romberg test) 시 눈을 뜨고 있을 때에도 심한 불안정성 을 보였다. 손가락코검사(finger-nose test) 및 빠른교대운동 검사(rapid alternative movement test) 등 소뇌기능검사에서 는 정상 소견을 보였다.

상기 문진 및 신체검사 소견으로 중추성 현훈을 의심하여 뇌혈관 자기공명영상을 시행하였으며, T2 강조영상에서 환자 의 뇌량 부위에 과증강되는 낭종성 병변이 관찰되었으나, 현 재 증상과는 관련 없는 부위로 사료되었다. 혈액검사 및 척 추천자검사에서 특이 소견은 발견되지 않았으며, 그동안의 소견을 종합하여 어지럼증의 원인으로 신생물딸림증후군을 의심하여 자가항체 검사(ANA, anti-dsDNA, anti-Ro, anti$\mathrm{La})$ 와 신경계자가항체검사(anti-Hu, anti-Ri, anti-Yo, anti$\mathrm{NMO})$ 및 양전자방출단층촬영(PET-CT)을 시행하였다. 상기

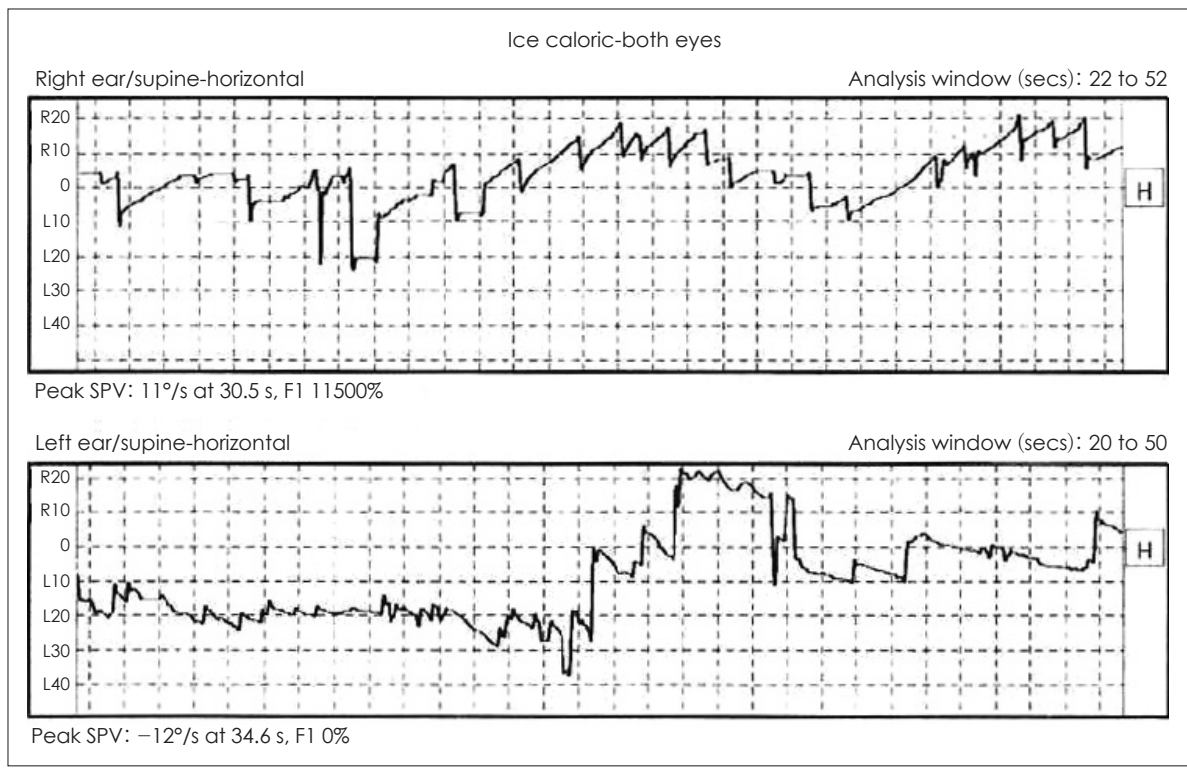

Fig. 2. Caloric test of the patient. SPV: slow phase peak velocity. 

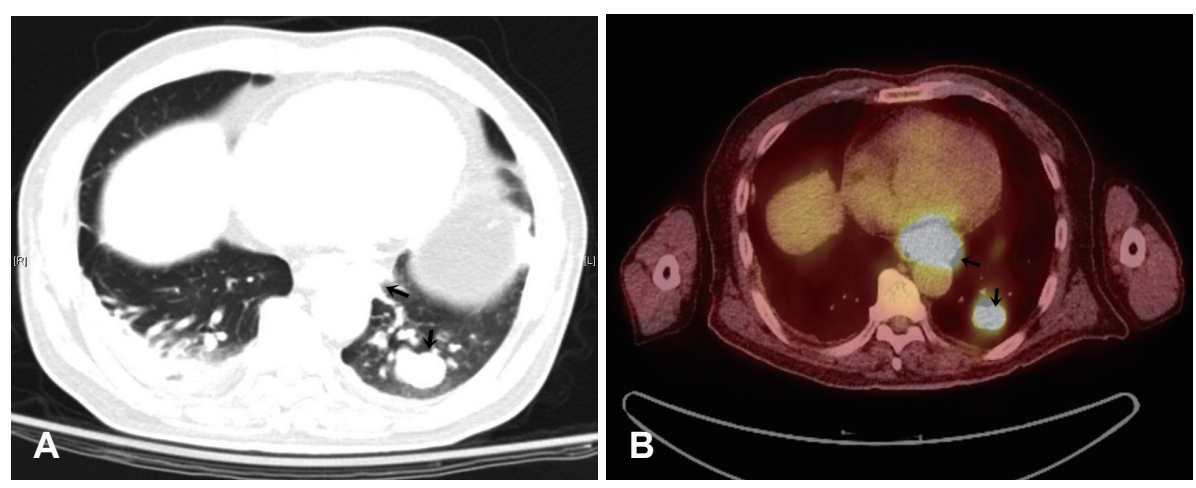

Fig. 3. Radiologic image of lung and mediastinal mass (arrows) of the patient. Confirmed as small cell lung cancer by trans-bronchial lung biopsy. Chest CT (A) and PET-CT (B).
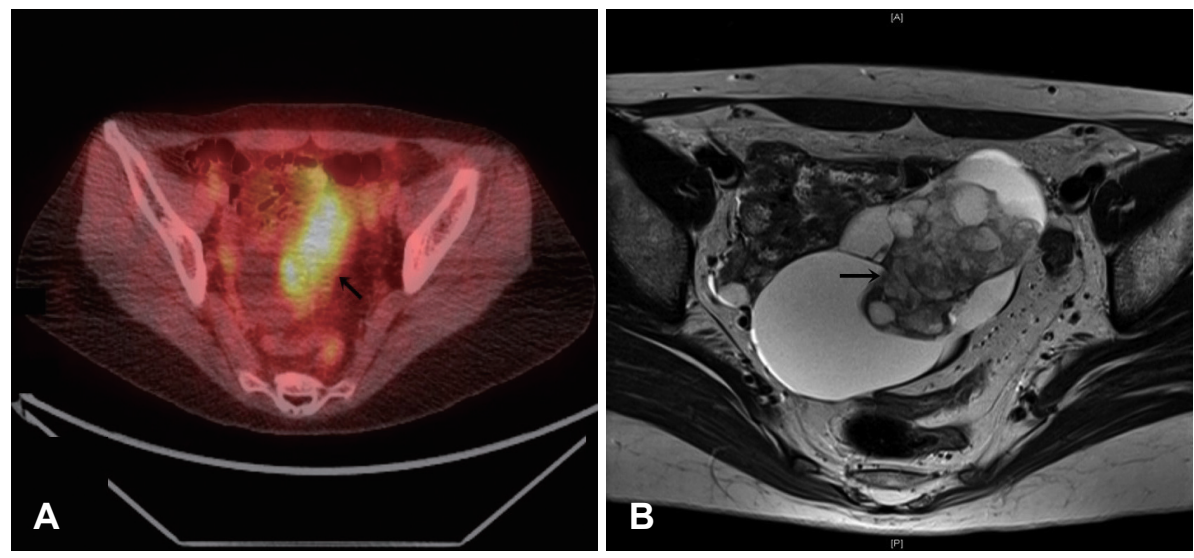

Fig. 4. Pelvic mass (arrows) of the paitent, confirmed as immature teratoma of ovary, left. PET-CT $(A)$ and pelvis MRI (B).

자가항체검사는 증례 1 과 동일한 기관에 위탁하여 동일한 방법으로 시행하였다. 환자 혈액에서 자가항체는 검출되지 않았으나 양전자방출단층촬영에서 조영증강을 보이는 불균 일한 종괴가 골반강에서 관찰되었다(Fig. 4). 이후 시행한 골반 자기공명영상에서 종괴는 난소암 의심 소견을 보여 산부인과 로 전과하여 좌측 자궁난관난소절제술과 림프절절제술을 시 행 받았다. 종괴는 조직병리학 검사 결과 미성숙기형종으로 확인되었고, 수술 후 보조항암화학요법 병행 중이다. 어지럼 증 및 보행실조 증상의 완화를 위하여 수술 후 5일간 고용량 스테로이드 약물(Solu-medrol inj., Methylprednisolone $\mathrm{Na}$ succinate, $500 \mathrm{mg} / \mathrm{V}, 1000 \mathrm{mg}$ per day)을 투여하였으나, 증 상 호전이 미미하여 중단하고 면역글로불린(IV globulin SN inj., Humn immunoglobulin gamma, 2.5 g/V, 20 g per day) 을 5일간 정맥 내 주사 투여 후 증상 호전되었다.

\section{고 찰}

신생물딸림신경증후군(paranoplastic neurologic syndrome) 은 신생물딸림증후군(paraneoplastic syndrome)의 한 형태로 중추부터 말초까지 전체 신경계의 어떤 부분이든지 침범할 수 있으며, 암과 관련된 자가항체가 신경계의 특정 항원과 국 소적인 자가면역반응을 일으켜 증상을 야기한다. 신생물딸
림신경증후군은 여러 가지 다른 증후군을 포함하는데, 각각 의 증후군마다 증상과 병태생리가 다르다. 전형적 증후군(classical neurological syndrome)으로 분류되는 질환으로는 뇌 척수염(encephalomyelitis), 변연계뇌염(limbic encephalitis), 아급성소뇌변성(subacute cerebellar degeneration), 감각신경 병증(sensory neuronopathy), 안구간대경련-근간대경련증 후군(opsoclonus-myoclonus syndrome), 만성위장관거짓폐 색(chronic gastrointestinal pseudoobstruction), 램버트-이 튼증후군(Lambert-Eaton myasthenic syndrome)이 있다.

신생물딸림신경증후군의 진단기준은 1) 안구간대경련-근 간대경련증후군 등의 전형적인 신경학적 증후군의 발현 후 5 년 내로 암이 발견되거나, 2) 비전형적 신경학적 증후군 및 증상이 암의 치료로 완화되거나, 3) 비전형적 신경학적 증후 군 및 증상과 신생물딸림증후군 관련 자가항체가 함께 발견 되고 5년 내로 암이 발견되거나, 4) 암이 발견되지 않았지만 확실한 종류의 신생물딸림증후군과 관련된 신경계자가항체 (anti-Hu Ab, anti-Yo Ab, anti-CV2 Ab, anti-Ri Ab, anti-Ma2 $\mathrm{Ab}$ or anti-anphiphysin $\mathrm{Ab}$ )가 발견되는 경우이다. ${ }^{8)}$

지금까지 알려진 신생물딸림신경증후군에 관여하는 신경 계자가항체로는 난소암과 유방암에서 나타나는 푸르킨예세 포질 항체-1(anti-Yo, PCA-1), 소세포폐암에서 나타나는 푸 르킨예세포질 항체-2(PCA-2)와 항신경핵 항체-1(anti-Hu, 
ANNA-1), 그리고 고환배아세포종양에서 나타나는 anti-Ma2/ $\mathrm{Ta}$ 항체가 있고, 그 외에 anti-CV2/CRMP5 항체, anti-Ri 항 체, anti-Tr 항체, anti-amphiphysin 항체 그리고 anti-VGCC 항체가 있다. 이 항체들은 중추신경계에 존재하는 각각의 특 정 항원과 자가면역반응을 일으켜 증상을 야기한다. ${ }^{2}$ 그러나 모든 신생물딸림증후군 환자의 혈청에서 항체가 발견되는 것은 아니다. Ducray 등')이 2014년 발표한 논문에서는 대상 이 된 신생물딸림소뇌변성 환자의 $18 \%$ 의 혈청에서 항체가 검 출되지 않았다고 보고되었고, Honnorat과 Antoine ${ }^{8)}$ 은 2007 년 신생물딸림신경증후군이 있는 환자의 최대 $50 \%$ 에서 항 체가 검출되지 않는다고 보고하였다. 따라서 항체의 검출 유 무 만으로 신생물딸림증후군을 배제할 수 없다. 실제로 혈청 양성과 혈청 음성 환자 사이에서 신생물딸림증후군을 진단 하여 악성 종양을 발견하고 치료를 시작하는 데에 걸리는 시 간은 차이가 없는 것으로 보고되었으며," ${ }^{9)}$ 이는 진단에 있어 항 체의 검출 여부보다는 증상이 더 중요하다는 것을 시사한다.

안구간대경련은 불규칙한 진폭과 무작위 방향으로 반복적 으로 나타나는 불수의적 수평 혹은 수직 방향의 안구운동이 며 근간대경련이란 갑작스럽고 빠른 발작적인 근육의 수축 현상을 지칭한다. 안구간대경련-근간대경련증후군은 감염, 독성대사장애, 신생물딸림신경증후군 등에서 나타나며 대부 분의 경우가 신생물딸림신경증후군이 원인이다. 소아의 경우 증상이 있는 환자의 $50 \%$ 에서 신경모세포종이 발견되고, 성 인은 소세포폐암이 발견되는 경우가 대부분이고 유방암, 난 소암이 발견된 보고도 있다. 자가항체는 anti-Ri 항체가 가장 자주 발견된다고 한다. ${ }^{10)}$ 발병 기전은 명확히 밝혀지지는 않 았으나 아마도 소뇌 꼭지핵(fastigial nucleus)의 억제기능이 소 실되면서 외안근과 사지 근육의 불수의적 수축이 나타나는 것으로 추정하고 있다. ${ }^{2)}$

신생물딸림신경증후군은 뇌 자기공명영상 등의 영상의학적 검사로는 진단하기 어렵다. 변연계뇌염(limbic encephalitis) 의 경우 종종 액체감약반전회복(FLAIR) 뇌 자기공명영상에 서 내측측두엽의 신호가 강화되는 소견을 보이는 경우가 있고, 신생물딸림소뇌변성(paraneoplastic cerebellar degeneration) 의 경우 증상이 진행됨에 따라 전반적인 소뇌의 위축이 온다 고 알려져 있으나 발병 초기에는 이상 소견을 발견하기 어렵 다. 이외에 다른 종류의 신생물딸림신경증후군에서는 거의 대부분에서 뇌 자기공명영상은 정상소견을 보인다고 한다. ${ }^{8)}$ 따라서 뇌 자기공명영상은 중추신경계의 다른 질병과 감별진 단을 위한 목적 외에 진단적 도구로 이용하기는 어렵다. 따라 서 병의 진단을 위해서는 뇌 자기공명영상이나 혈청학적 검 사와 더불어, 기저의 원발암을 찾으려는 노력이 필요하다. ${ }^{3)}$ 만약 자가항체가 발견되었다면, 그 항체의 종류에 따라 원발
암이 있을 가능성이 높은 신체 부위를 특정하여 국소적인 영 상의학적 검사를 진행하고, 그럼에도 불구하고 원발암을 찾 을 수 없다면 그때 양전자방출단층촬영을 시행하는 것이 바 람직하다. ${ }^{11)}$ 하지만 자가항체가 발견되지 않아 원발암이 있을 것이라 예상되는 부위를 특정할 수 없는 경우에는 전신에 대 한 양전자방출단층촬영이 진단에 많은 도움을 줄 수 있다. ${ }^{12)}$

신생물딸림신경증후군을 치료하기 위해 자가항체에 의한 면역반응을 감소시키기는 방법들로 혈장교환, 면역억제치료, 면역글로불린 정맥투여 등의 치료법들이 주로 보고되었지만 약물치료에 대한 반응은 좋지 않았다. 다만, 가장 효과적인 치 료방법은 원발암의 제거나 축소라고 알려져 있기에, 원발암 의 탐색과 치료가 매우 중요하다고 할 수 있다. ${ }^{8)}$ 하지만 이마 저도 대부분의 경우에서 비가역적인 신경학적 퇴행을 동반하 기 때문에 예후는 좋지 않은 것으로 알려져 있다. 신생물딸림 신경증후군의 하나인 안구간대경련-근간대경련증후군 역시 주로 면역억제를 통한 치료 방법이 시도되고 있고 항전간제 를 투여하는 방법도 보고되었다. 소아가 성인보다 치료에 잘 반 응하며, 신생물딸림신경증후군과 관련이 없는 안구간대경련근간대경련증후군의 경우에 예후가 더 좋다고 알려져 있다.")

본 증례에서 확인하였듯이 안구간대경련(opsoclonus)과 근간대경련(myoclonus)이 신체검사에서 보이는 경우 영상의 학적 검사와 혈청학적 검사가 정상이라 하더라도 신생물딸림 신경증후군에 대한 가능성을 항상 염두 하여 양전자방출단 층촬영을 비롯한 암에 대한 선별검사를 시행하는 것이 바람 직 하다.

\section{ORCID}

Sung Huhn Kim ～https://orcid.org/0000-0003-4408-3066

Seong Hoon Bae https://orcid.org/0000-0001-9243-9392

\section{REFERENCES}

1) Honnorat J, Viaccoz A. New concepts in paraneoplastic neurological syndromes. Rev Neurol (Paris) 2011;167(10):729-36.

2) Dalmau J, Rosenfeld MR. Paraneoplastic syndromes of the CNS. Lancet Neurol 2008;7(4):327-40.

3) Peterson K, Rosenblum MK, Kotanides H, Posner JB. Paraneoplastic cerebellar degeneration. I. A clinical analysis of 55 anti-Yo antibodypositive patients. Neurology 1992;42(10):1931-7.

4) Bataller L, Graus F, Saiz A, Vilchez JJ; Spanish Opsoclonus-Myoclonus Study Group. Clinical outcome in adult onset idiopathic or paraneoplastic opsoclonus-myoclonus. Brain 2001;124(Pt 2):437-43.

5) Scarff JR, Iftikhar B, Tatugade A, Choi J, Lippmann S. Opsoclonus myoclonus. Innov Clin Neurosci 2011;8(12):29-31.

6) Kim H, Lim Y, Kim KK. Anti-Ri-antibody-associated paraneoplastic syndrome in a man with breast cancer showing a reversible pontine lesion on MRI. J Clin Neurol 2009;5(3):151-2.

7) Lee YM, Sim WH, Yoon SO, Kim SY, Park JS, Kho BG, et al. A case of cranial nerve palsy as a paraneoplastic syndrome in non-small cell lung cancer. Tuberc Respir Dis 2011;70(2):160-4.

8) Honnorat J, Antoine JC. Paraneoplastic neurological syndromes. 
Orphanet J Rare Dis 2007;2:22.

9) Ducray F, Demarquay G, Graus F, Decullier E, Antoine JC, Giometto B, et al. Seronegative paraneoplastic cerebellar degeneration: the PNS Euronetwork experience. Eur J Neurol 2014;21(5):731-5.

10) Bataller L, Rosenfeld MR, Graus F, Vilchez JJ, Cheung NK, Dalmau J. Autoantigen diversity in the opsoclonus-myoclonus syndrome. Ann Neurol 2003;53(3):347-53.

11) Antoine JC, Cinotti L, Tilikete C, Bouhour F, Camdessanche JP,
Confavreux C, et al. $\left[{ }^{18} \mathrm{~F}\right]$ fluorodeoxyglucose positron emission tomography in the diagnosis of cancer in patients with paraneoplastic neurological syndrome and anti-Hu antibodies. Ann Neurol 2000; 48(1):105-8.

12) Rees JH, Hain SF, Johnson MR, Hughes RA, Costa DC, Ell PJ, et al. The role of [18F]fluoro-2-deoxyglucose-PET scanning in the diagnosis of paraneoplastic neurological disorders. Brain 2001;124(Pt 11): 2223-31. 